\begin{tabular}{l|l|l|l} 
Cose Reports in & $\begin{array}{l}\text { Case Rep Neurol 2010;2:37-45 } \\
\text { Dol: } 10.1159 / 000313953\end{array}$ & Published online: May 7, 2010 & $\begin{array}{l}\text { ○ 2010 S. Karger AG, Basel } \\
\text { ISSN 1662-680X } \\
\text { www.karger.com/crn }\end{array}$
\end{tabular}

\title{
A Case Report of Cerebral Venous Thrombosis in Polycythemia Vera Presenting with Intracranial and Spinal Subdural Hematoma
}

\author{
Nermin Görkem Sirin Nilufer Yesilot Esme Ekizoglu \\ Nur Keles Rezzan Tuncay Oguzhan Coban \\ Sara Zarko Bahar
}

Edip Aktin Stroke Unit, Department of Neurology, Istanbul University, Istanbul

Medical School, Istanbul, Turkey

\section{Key Words}

Cranial subdural hematoma - Spinal subdural hematoma $\cdot$ Concomitant $\cdot$ Cerebral venous thrombosis - Polycythemia vera

\begin{abstract}
Spinal subdural hematoma (SDH) is a rare condition and can be caused by several factors. Concomitant cranial and spinal SDH is even much less common. We present a 77-yearold male patient with lower back pain, paraparesis, and urinary retention following a sudden onset headache. Imaging revealed concomitant cranial and spinal SDH related to cerebral venous thrombosis (CVT) associated with hemorrhagic venous infarct. Laboratory examinations were consistent with polycythemia vera. There was no history of trauma and previous cranial surgery. Brain angiography did not reveal any evidence of arteriovenous fistula or vascular malformation. Since lower back pain occurred shortly after the headache and there was no other reasonable explanation for spinal hemorrhage, we suppose that the mechanism of spinal SDH is the migration of blood from the intracranial compartment. Therefore, this is the first report of concomitant spinal SDH and cerebral hemorrhage associated with CVT in a patient with myeloproliferative disease.
\end{abstract}

\section{Introduction}

Spinal subdural hematoma $(\mathrm{SDH})$ is a rare condition and is encountered in case of trauma, lumbar puncture, hemostatic disorders, including anticoagulation therapy, 


\begin{tabular}{l|l|l|l} 
Case Reports in & $\begin{array}{l}\text { Case Rep Neurol 2010;2:37-45 } \\
\text { D01: } 10.1159 / 000313953\end{array}$ & Published online: May 7, 2010 & $\begin{array}{l}\text { @ 2010 S. Karger AG, Basel } \\
\text { ISSN 1662-680X } \\
\text { www.karger.com/crn }\end{array}$ \\
\hline
\end{tabular}

vascular malformations and prior spinal surgery [1-4]. Concomitant cranial and spinal $\mathrm{SDH}$ are extremely rare and the majority of the cases have previously had cranial surgery [3]. Here we present a case of concomitant cranial and spinal SDH in a patient with cerebral venous thrombosis (CVT) and polycythemia vera (PV).

\section{Case Report}

A 77-year-old male patient was referred to our clinic with lower back pain, gait disturbance and urinary retention. Two weeks before, he had had a sudden onset headache, nausea and vomiting, followed by back pain radiating to the legs developing within the following half hour. Cranial computed tomography was performed $3 \mathrm{~h}$ later and revealed an intracerebral hematoma spreading to the subdural space in the right temporal region (fig. 1a). Cranial MRI on the third day also showed a right temporal hematoma extending to the subdural space (fig. 1b). The headache subsided within 3 days, while the back pain worsened and gait disturbance with urinary retention developed.

At admission, the neurological examination revealed bilateral papilla edema and meningeal signs. Laseque's sign was positive bilaterally. The motor examination showed mild paraparesis. No sensory loss was found. Deep tendon reflexes were decreased and bilateral Achilles reflexes were absent. Flexor plantar responses were found. Urinary retention was evident.

MRI of the dorsal and lumbar spine revealed a SDH encompassing the whole lumbar spine (igg. 2 ). The hematoma seen as $T_{1}$ hyperintensity was compressing the cauda equina fibers. The subdural location could be assessed by the presence of the hypointense dura demarcating the preserved epidural fat planes and limiting the hematoma. The patient's medical history was significant for hypertension and hyperlipidemia. He was a heavy drinker and smoker. He had been using $500 \mathrm{mg}$ acetyl salicylic acid daily for 4 years.

On laboratory examination, hematocrit level was $53.8 \%(37.0-50.0)$, leukocyte count was $20.610^{3} / \mu \mathrm{l}$ (4.0-11.0), granulocyte count was $17.510^{3} / \mu \mathrm{l}(9.0-17.0)$, platelet count was $82110^{3} / \mu \mathrm{l}(150-400)$, erythropoetin level was $1.2 \mathrm{mlU} / \mathrm{ml}(2.59-18.5)$, the leukocyte alkaline phosphatase score was increased. $\mathrm{Bcr}-\mathrm{abl}$ translocation gene was negative, JAK2 V617F mutation was present. These findings were consistent with PV. Other laboratory tests to evaluate a clotting disorder were not performed. Phlebotomy and hydroxyurea therapy was started. There was no evidence of bleeding in other organs. Within 2 weeks of hospitalization, the lower back pain resolved, gait disturbance and paraparesis improved and he was discharged.

One week later he had a generalized tonic-clonic seizure resulting in left hemiparesis and he was readmitted. Cranial MRI showed a new right frontal SDH and a right frontoparietal hemorrhagic lesion. Superior sagittal sinus was hyperintense on sagittal $\mathrm{T}_{1}$-weighted images compatible with CVT (fig. 3 ). Brain angiography did not reveal any evidence of arteriovenous fistula or vascular malformation and confirmed the superior sagittal sinus, right transverse and sigmoid sinus thrombosis (ig. 4 ). Because of massive cranial and spinal hemorrhages we preferred to proceed without anticoagulant therapy. After 3 weeks of hospitalization the patient was discharged with antiepileptics and hydroxurea. Blood parameters improved in the first 3 weeks.

One week later he had a seizure followed by worsening of the left hemiparesis and was admitted for the third time. Cranial MRI showed large white matter hyperintensity around the old hemorrhagic lesions of the right hemisphere on $\mathrm{T}_{2}$-weighted images (fig. 5). Because of the progressive worsening of the right hemispheric lesions and recurrent seizures, anticoagulant therapy was started. Four months later, the left hemiparesis improved. Anticoagulation was stopped after 1.5 years. At 2 years of followup, his neurological condition remains stable without seizures.

\section{Discussion}

PV is a myeloproliferative disorder manifested by overproduction of erythrocytes, granulocytes, and megacaryocytes. The incidence of thrombosis and bleeding in PV was reported to be $12-39$ and 1.7-20\%, respectively. In PV, arterial, venous or microcirculatory thrombosis may occur. The frequency of venous events is less than for arterial ones. Bleeding manifestations in PV include ecchymosis, epistaxis, menorrhagia 


\begin{tabular}{l|l|l|l} 
Case Reports in & $\begin{array}{l}\text { Case Rep Neurol 2010;2:37-45 } \\
\text { D0l: } 10.1159 / 000313953\end{array}$ & Published online: May 7, 2010 & $\begin{array}{l}\text { @ 2010 S. Karger AG, Basel } \\
\text { ISSN 1662-680X } \\
\text { www.karger.com/crn }\end{array}$ \\
\hline
\end{tabular}

and gingival hemorrhage, all present in the skin and mucous membranes, suggesting defective primary hemostasis [5].

Spinal hematoma is a rare neurological disorder. Because of its rarity, there have been no reported reliable data on the incidence of spinal hematomas. In a review of 613 spinal hematomas, published between 1826 and 1996, Kreppel et al. reported that 75\% were epidural, $15.7 \%$ subarachnoid and $4 \%$ subdural $[1,6]$.

Spinal SDH can be caused by several factors [1, 3, 4, 7-13]. In the largest series of nontraumatic acute spinal SDH, Domenicucci et al. [2] reviewed 101 published cases additionally to 5 of their own. The most common predisposing factor observed in 57 of 106 patients was coagulopathy (54\%). Of these 57 patients, 37 were on anticoagulant therapy and nearly all of the SDH occurred following lumbar puncture (35/37) [2]. The origin of bleeding in spinal SDH is unclear. It may originate from a subarachnoid hemorrhage dissecting through the arachnoid membrane into the subdural space or a rupture of intraspinal vessels because of the sudden increase in intraabdominal and intrathoracic pressure $[3,4,14,15]$.

Concomitant cranial and spinal SDH is even much less common. Jain et al. [3] published a case report and reviewed 11 cases published previously. The majority (9/11) of the cases of concomitant cranial and spinal SDH either had previously had cranial surgery (5 cases), or a history of trauma (4 cases) [3]. Lee et al. reported 15 cases of spinal SDH after cranial surgery including their own [4]. A case of cranial and spinal SDH after epidural anesthesia has recently been reported [14].

Although the actual mechanism of concomitant cranial and spinal SDH is not completely understood, the most commonly accepted hypothesis assumes a downward movement of blood from the intracranial space caused by gravity $[3,4,8-16]$. This is possible due to the presence of an anatomic continuity between the cranial and spinal subdural space. In one case of cranial SDH, a redistribution of hemorrhage to the spinal subdural space has been implicated as a mechanism responsible for the rapid resolution [16]. The presence of blood in the posterior fossa, evident in some of these cases, was also thought to support the migration theory $[3,10-12]$.

In the available literature, only 3 cases of concomitant cranial and spinal SDH with no history of trauma and previous cranial surgery have been published. Yamaguchi et al. [12] reported a patient presenting with low back pain, numbness and motor weakness in both legs, and imaging revealed cranial and spinal SDH. The only predisposing factor was oral antiplatelet therapy in this patient [12]. Jain et al. reported spontaneous cranial and spinal $\mathrm{SDH}$ in a patient with severe thrombocytopenia due to aplastic anemia [3]. Yang et al. published a case of left frontoparietal and spinal SDH without any evidence of coagulopathy or vascular abnormality in the brain and spinal angiography [13].

MRI studies of the present case showed concomitant intracranial and spinal SDH. There was no history of trauma and previous cranial surgery. Although the spinal MRI was performed 12 days later, lower back pain occurred within half an hour of a sudden onset headache, followed by paraparesis and urinary retention. This clinical correlation and the dissemination of the parenchymal hemorrhagic lesion to the frontal and tentorial subdural space, evident on the early brain CT and MRI, suggest that the mechanism of spinal SDH is the migration of blood from the intracranial compartment, similar to what has been reported in the literature.

In the present case, one underlying factor of concomitant intracerebral and spinal hematomas must be CVT associated with hemorrhagic venous infarct. Within 3 weeks, 


\begin{tabular}{l|l|l|l}
$\begin{array}{c}\text { Cose Reports in } \\
\text { Reulviojy }\end{array}$ & $\begin{array}{l}\text { Case Rep Neurol 2010;2:37-45 } \\
\text { D0I: } 10.1159 / 000313953\end{array}$ & $\begin{array}{l}\text { Published online: May 7, 2010 } 2010 \text { S. Karger AG, Basel } \\
\text { ISSN 1662-680X } \\
\text { www.karger.com/crn }\end{array}$ \\
\hline
\end{tabular}

the brain imaging showed two parenchymal hemorrhages, subsequently $\mathrm{T}_{2}$

hyperintensities developed in the same region. At the same time, angiography revealed superior sagittal sinus, right transverse and sigmoid sinus thrombosis which could impair venous drainage of the right hemisphere. Therefore, we concluded that the hemorrhages developed secondary to cortical vein thrombosis. Hemorrhagic venous infarct is one of the most frequent initial presentations of CVT [17]. Massive subarachnoid hemorrhage might occur in the course of CVT [18]. In one of the 32 cases with CVT caused by other etiologies than Behçet's disease, recurrent lobar hematomas were a remarkable clinical presentation [19]. SDH is an unusual complication of CVT. Only two case reports have been published in the available literature. One is an aplastic anemia case which occurred during androgen treatment with tentorial SDH and CVT [20]. The other one is a case of chronic SDH resulting from CVT [21].

Concomitant cranial and spinal SDH was the initial presentation in this case of PV. In the literature, there is one case of PV with spontaneous spinal SDH which was not related with thrombosis [22]. As far as we know, this is the first report of concomitant spinal $\mathrm{SDH}$ and cerebral hemorrhage associated with CVT in a patient with myeloproliferative disease.

Fig. 1. Non-contrast CT scan obtained $3 \mathrm{~h}$ after the sudden onset headache. a Right temporal hematoma (asterisk) extending to the right temporal and tentorial subdural space (arrows). b $\mathrm{T}_{2}$-weighted axial MRI section obtained on day 3. Right temporal hematoma and its extensions to the subdural space (asterisk).

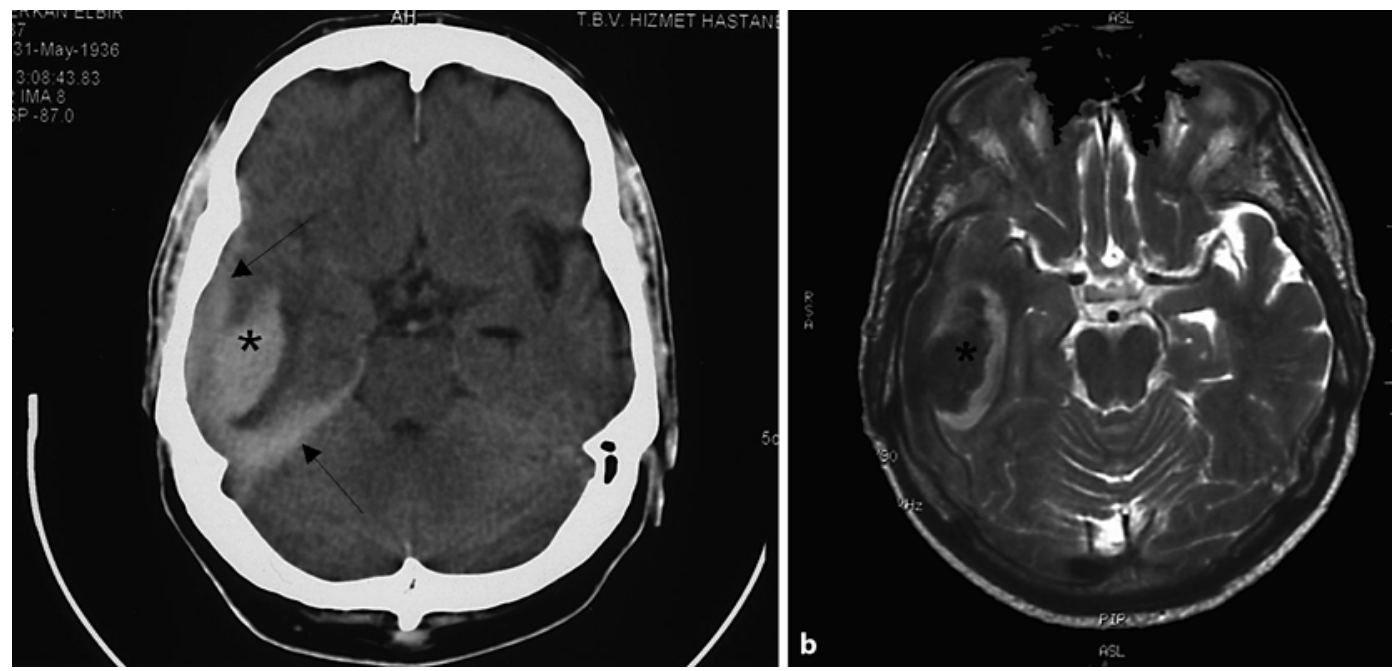




\begin{tabular}{l|l|l|l} 
Case Reports in & $\begin{array}{l}\text { Case Rep Neurol 2010;2:37-45 } \\
\text { D0I: } 10.1159 / 000313953\end{array}$ & Published online: May 7, 2010 & $\begin{array}{l}\text { ○ 2010 S. Karger AG, Basel } \\
\text { ISSN 1662-680X } \\
\text { www.karger.com/crn }\end{array}$ \\
\hline
\end{tabular}

Fig. 2. $\mathrm{T}_{1}$-weighted MRIs. Sagittal and axial planes. a $\mathrm{T}_{1}$ hyperintense blood signal. Subdural hematoma surrounding and compressing the cauda equina in the lumbosacral region. $\mathbf{b}$ Note the subdural hematoma extension in the thoracal region. $\mathbf{c}$, $\mathbf{d}$ Contraction and compression of the cauda equina fibers with $\mathrm{T}_{1}$ hyperintense subdural space hematoma. The hematoma is limited by the hypointense dura (arrows) which also demarcates the preserved epidural fat planes.

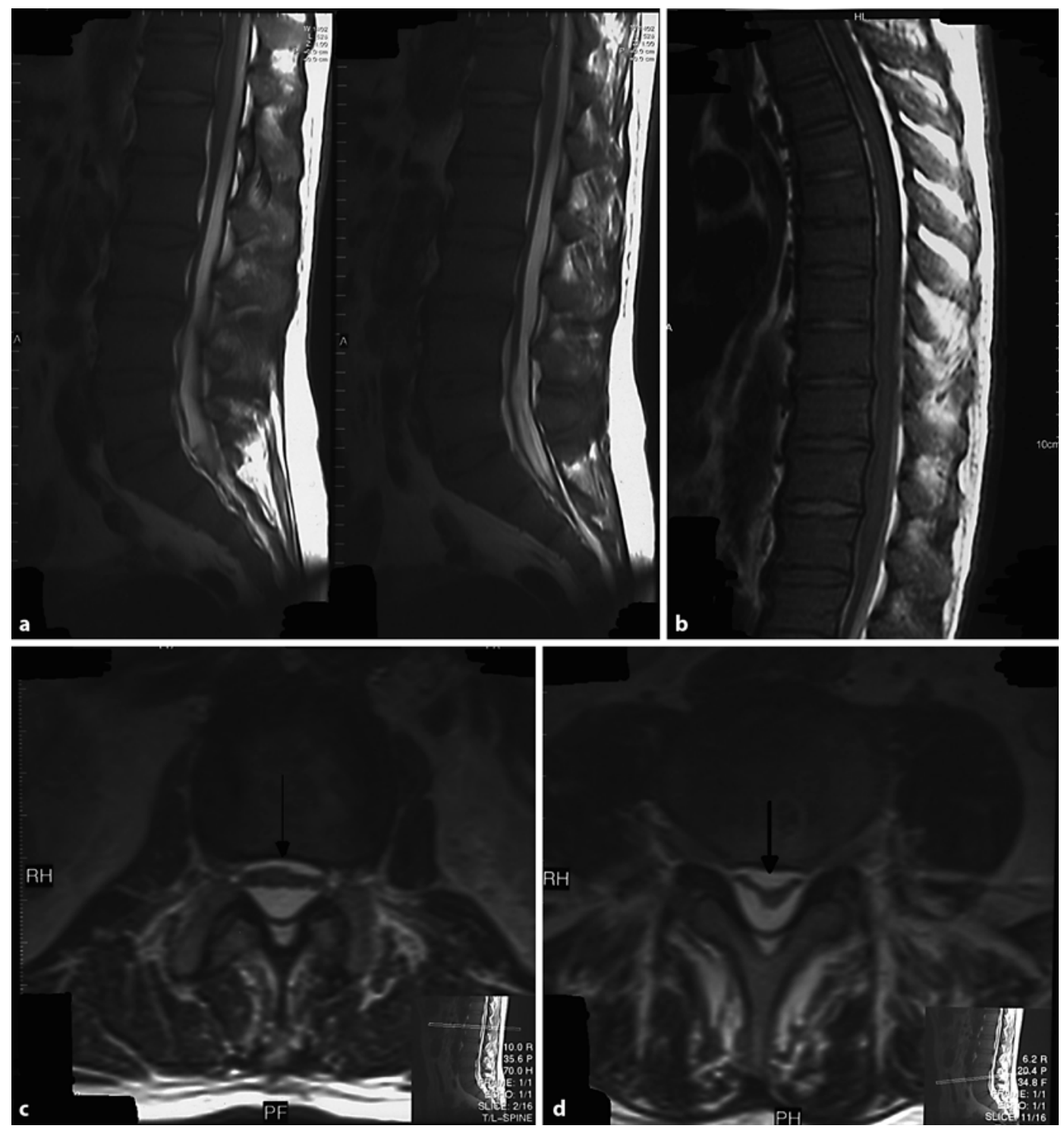




\begin{tabular}{l|l|l|l}
$\begin{array}{c}\text { Cose Reports in } \\
\text { Reulviojy }\end{array}$ & $\begin{array}{l}\text { Case Rep Neurol 2010;2:37-45 } \\
\text { D0I: } 10.1159 / 000313953\end{array}$ & $\begin{array}{l}\text { Published online: May 7, 2010 } 2010 \text { S. Karger AG, Basel } \\
\text { ISSN 1662-680X } \\
\text { www.karger.com/crn }\end{array}$ \\
\hline
\end{tabular}

Fig. 3. MRI obtained at the 5th week after onset. a Fluid-attenuated inversion recovery, axial section. Newly evolved right posterior frontal parietal hemorrhagic lesions, and right anterior frontal subdural hematoma. b $\mathrm{T}_{1}$-weighted mid sagittal section. Superior sagittal sinus appears hyperintense.
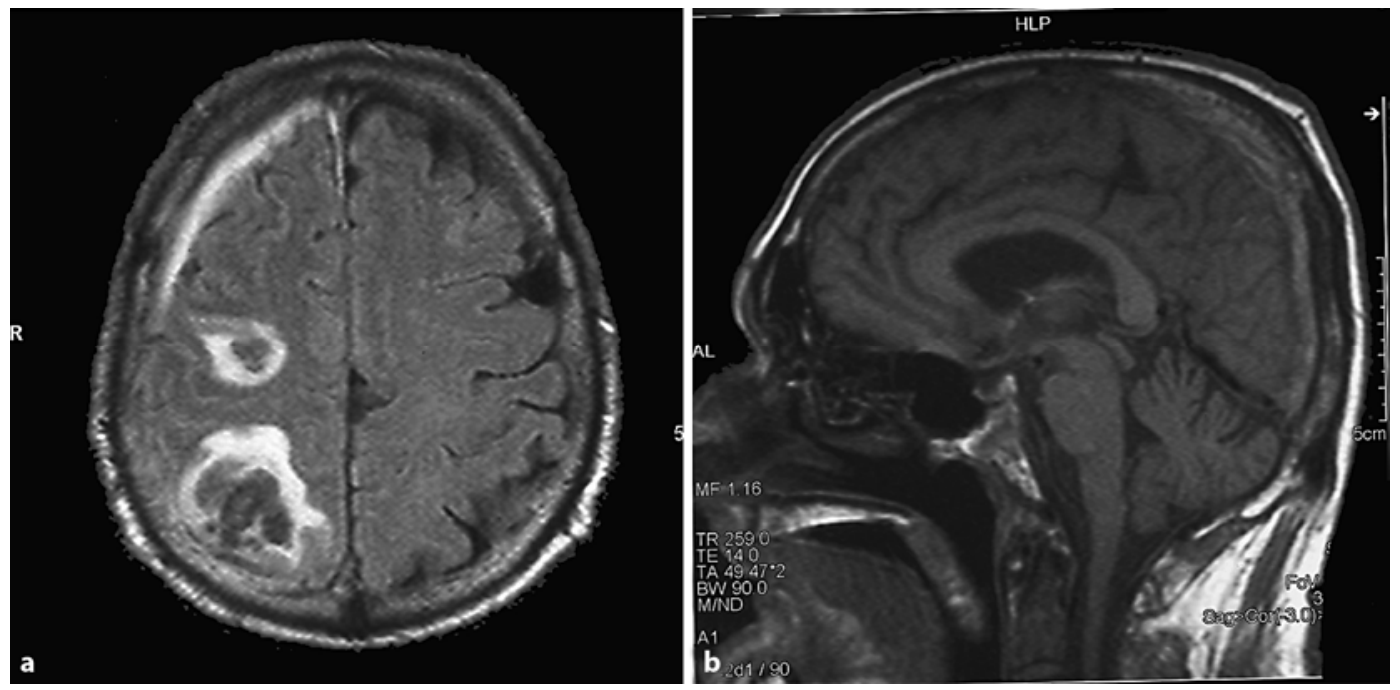

Fig. 4. Catheter angiography: incomplete, inadequate filling of the superior sagittal sinus, transverse and sigmoid sinuses.
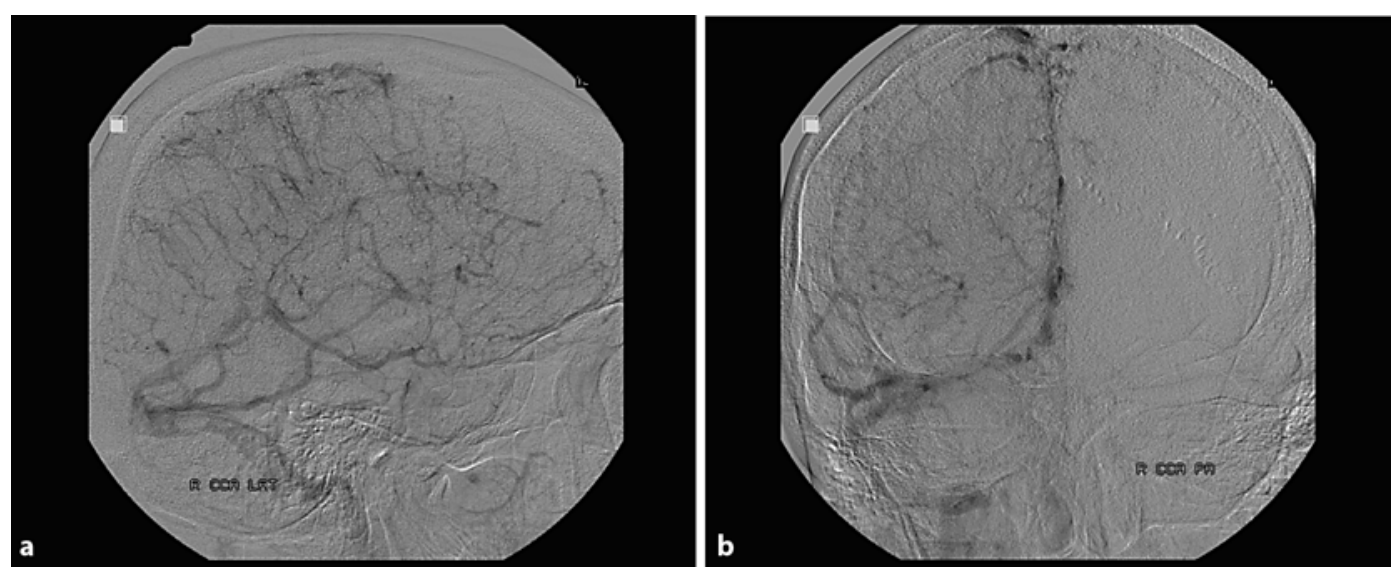


\begin{tabular}{l|l|l|l} 
Case Reports in & $\begin{array}{l}\text { Case Rep Neurol 2010;2:37-45 } \\
\text { D0I: } 10.1159 / 000313953\end{array}$ & Published online: May 7, 2010 & $\begin{array}{l}\text { ○ 2010 S. Karger AG, Basel } \\
\text { ISSN 1662-680X } \\
\text { www.karger.com/crn }\end{array}$ \\
\hline
\end{tabular}

Fig. 5. MRI obtained at the 2 nd month. Fluid-attenuated inversion recovery, axial sections. Wide hyperintense areas evolved in the meantime suggestive of increasing edema in the affected region.

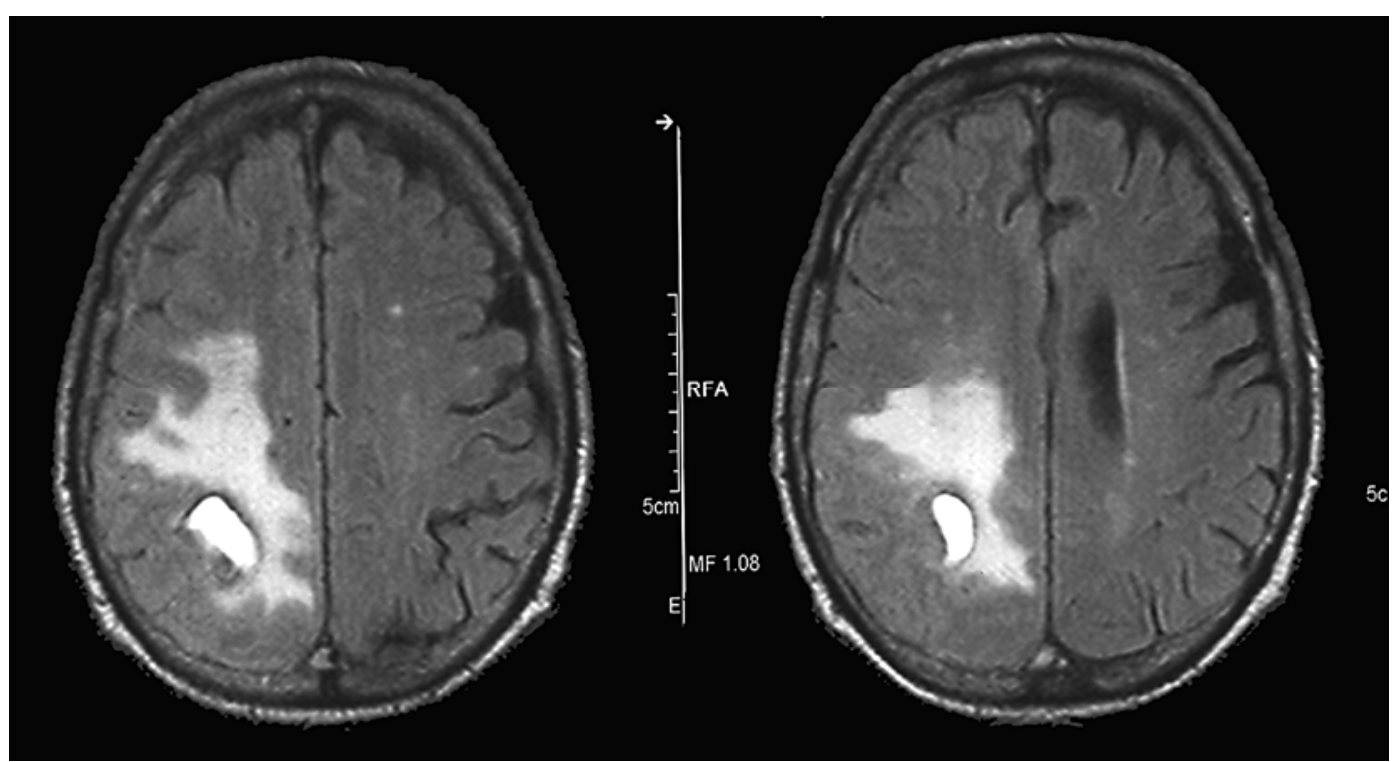




\begin{tabular}{l|l|l|l} 
Case Reports in & $\begin{array}{l}\text { Case Rep Neurol 2010;2:37-45 } \\
\text { Dol: } 10.1159 / 000313953\end{array}$ & Published online: May 7, 2010 & $\begin{array}{l}\text { ○ 2010 S. Karger AG, Basel } \\
\text { ISSN 1662-680X } \\
\text { www.karger.com/crn }\end{array}$ \\
\hline
\end{tabular}

\section{References}

1 Kreppel D, Antoniadis G, Seeling W: Spinal hematoma: a literature survey with meta-analysis of 613 patients. Neurosurg Rev 2003;26:1-49.

2 Domenicucci M, Ramieri A, Ciappetta P, Delfini R: Nontraumatic acute spinal subdural hematoma: Report of five cases and review of the literature. J Neurosurg 1999;91:65-73.

-3 Jain V, Singh J, Sharma R: Spontaneous concomitant cranial and spinal subdural haematomas with spontaneous resolution. Singapore Med J 2008;49:e53-e58.

-4 Lee TH, Su TM, Wang KW, Lee HL, Ho JT: Lumbosacral spinal subdural hematoma following burr hole craniotomy: case report and literature review. Clin Neurol Neurosurg 2007;109:282-286.

5 Elliott MA, Tefferi A: Thrombosis and haemorrhage in polycythaemia vera and essential thrombocythaemia. Br J Haematol 2005;128:275-290.

6 Skvortsova VI, Bahar SZ: Spinal strokes; in Fisher M (ed): Handbook of Clinical Neurology, part 2: Clinical Manifestations and Pathogenesis. Amsterdam, Elsevier, 2009, vol 93, pp 684-702.

7 Boukobza M, Haddar D, Boissonet M, Merland JJ: Spinal subdural haematoma: A study of three cases. Clin Radiol 2001;56:475-480.

8 Bortolotti C, Wang H, Fraser K, Lanzino G: Subacute spinal subdural hematoma after spontaneous resolution of cranial subdural hematoma: causal relationship or coincidence? Case report. J Neurosurg 2004;100:372-374.

-9 Hicdonmez T, Kilincer C, Hamamcioglu MK, Cobanoglu S: Paraplegia due to spinal subdural hematoma as a complication of posterior fossa surgery: case report and review of the literature. Clin Neurol Neurosurg 2006;108:590-594.

10 Shimizu S, Tachibana S, Maezawa H, Fujii K, Kan S: Lumbar spinal subdural hematoma following craniotomy - case report. Neurol Med Chir (Tokyo) 1999;39:299-301.

-11 Yamaguchi S, Hida K, Akino M, Yano S, Iwasaki Y: Spinal subdural hematoma: a sequela of a ruptured intracranial aneurysm? Surg Neurol 2003;59:408-412, discussion 412.

12 Yamaguchi S, Kurisu K, Arita K, Takeda M, Tani I, Araki O: Simultaneous cranial and spinal subdural hematoma. Neurol Med Chir (Tokyo) 2005;45:645-649.

13 Yang MS, Tung YW, Yang TH, Chai JW, Chen CC, Chan SW, Tu CW: Spontaneous spinal and intracranial subdural hematoma. J Formos Med Assoc 2009;108:258-261.

14 Rocchi R, Lombardi C, Marradi I, Di Paolo M, Cerase A: Intracranial and intraspinal hemorrhage following spinal anesthesia. Neurol Sci 2009;30:393-396.

15 Tillich M, Kammerhuber F, Reittner P, Leber KA, Szolar DH: Chronic spinal subdural haematoma associated with intracranial subdural haematoma: CT and MRI. Neuroradiology 1999;41:137-139.

16 Wong ST, Yuen MK, Fok KF, Yuen SC, Yam KY, Fong D: Redistribution of hematoma to spinal subdural space as a mechanism for the rapid spontaneous resolution of posttraumatic intracranial acute subdural hematoma: case report. Surg Neurol 2009;71:99-102, discussion 102.

17 Stam J: Thrombosis of the cerebral veins and sinuses. N Engl J Med 2005;352:1791-1798.

18 Zare M, Mirabdolbaghi M: Cerebral venous thrombosis presented as subarachnoid hemorrhage and treated with anticoagulants. J Res Med Sci 2005; 10:251-254.

19 Yesilot N, Bahar S, Yilmazer S, Mutlu M, Kurtuncu M, Tuncay R, Coban O, Akman-Demir G: Cerebral venous thrombosis in Behçet's disease compared to those associated with other etiologies. J Neurol 2009;256:1134-1142.

20 Chu K, Kang DW, Kim DE, Roh JK: Cerebral venous thrombosis associated with tentorial subdural hematoma during oxymetholone therapy. J Neurol Sci 2001;185:27-30.

-21 Takamura Y, Morimoto S, Uede T, Yamaki T, Minamida Y, Yamamura A, Nakagawa T: Cerebral venous sinus thrombosis associated with systemic multiple hemangiomas manifesting as chronic subdural hematoma - case report. Neurol Med Chir (Tokyo) 1996;36:650-653. 


\begin{tabular}{l|l|l|l} 
Case Reports in & $\begin{array}{l}\text { Case Rep Neurol 2010;2:37-45 } \\
\text { D0I: } 10.1159 / 000313953\end{array}$ & Published online: May 7, 2010 & $\begin{array}{l}\text { ○ 2010 S. Karger AG, Basel } \\
\text { ISSN 1662-680X } \\
\text { www.karger.com/crn }\end{array}$ \\
\hline
\end{tabular}

22 Kalina P, Drehobl KE, Black K, Woldenberg R, Sapan M: Spinal cord compression by spontaneous spinal subdural haematoma in polycythemia vera. Postgrad Med J 1995;71:378-379. 